\title{
Strategic for Increasing Economic Value Added in the MSME Sector in the North Sumatra Region with the Acceleration Board Method and Initial Public Offering
}

\author{
Mangasi Sinurat ${ }^{1}$, Rico Nur Ilham ${ }^{2, *}$, Willy Cahyadi ${ }^{1}$ \\ ${ }^{1}$ Sekolah Tinggi Ilmu Ekonomi Bina Karya Tebing Tinggi, Indonesia \\ ${ }^{2}$ Faculty Economic and Bussiness Universitas Malikussaleh, Indonesia \\ "Corresponding Author.Email: riconulilham@unimal.ac.id
}

\begin{abstract}
The Covid-19 pandemic that occurred globally of course had an impact on various sectors, especially in the economic sector and of course also had a significant impact on tourism, the trade sector, industry including Micro, Small and Medium Enterprises (MSMEs) in Indonesia. Creative products have great potential to be able to deliver a city that has this industry to become a city with an advanced and independent creative economy. The use of information technology for the management of business resources for active products has been neglected, which in turn has administrative, financial, process, access to banking and financial institutions weaknesses. This research includes the type of literature study, research by looking for theoretical references and scientific journals that are relevant to the cases or problems found. The theoretical references obtained by the literature study serve as the basis for study foundations and the main tool in conducting research. This study uses literature studies, analysis based on several previous studies and scientific journals that discuss Economic Value Added as an indicator for evaluating the good performance of an MSME. One of the strategies to increase added value for the MSME sector in the province of North Sumatra is by using the Economic Value-Added method and implementing efforts to cooperate with the Indonesia Stock Exchange through the acceleration board mechanism and Initial Public Offering (IPO) to obtain long-term funding convenience and introduce MSME business units to the wider community to become a middle-class public company.
\end{abstract}

Keywords: Pandemic Covid-19, Economic Value Added, Acceleration Board, Initial Public Offering (IPO)

\section{INTRODUCTION}

\section{Background}

The Covid-19 pandemic that occurred globally of course had an impact on various sectors, especially in the economic sector. This economic impact was felt not only domestically, but also globally. International Monetary Fund (IMF), which projects the global economy to grow at minus 3\%. In Indonesia, this of course also has a significant impact on tourism, the trade sector, industry including Micro, Small and Medium Enterprises (MSMEs). In Indonesia, based on the latest data dated May 4, 2020, there have been 11,192 cases of Covid-19 in Indonesia. (covid19.go.id) The impact of Covid-19 has been seen directly from the massive layoffs in several MSMEs, the closure of several businesses which resulted in the dismissal of employees. According to a report from the Organization for Economic Co-operation and Development (OECD), the Covid-19 pandemic is affecting the economy from the supply and demand side. On the supply side, MSMEs reduce the supply of raw materials and unhealthy labor and supply chains that are also experiencing constraints. From the demand side, lack of demand and decreasing consumer confidence in a product. OECD also said that MSMEs had a significant impact on the conditions of Covid19. MSMEs were very vulnerable to being affected by business disruptions, because they often had direct contact with tourism, transportation and the culinary industry that needed suppliers all of which have been significantly affected by covid-19.

Data from the Ministry of Cooperatives and Small and Medium Enterprises shows that in 2018 there were 64,194,057 MSMEs in Indonesia and employed $116,978,631$ workers. Indonesia is dominated by MSMEs, which are the backbone of the national economy and have been seriously affected not only in terms of production and their income, but also on the 
number of workers that must be reduced due to this pandemic. MSMEs lack resilience and flexibility in facing this Pandemic due to several things such as the low level of digitization, difficulties in accessing technology and a lack of understanding of survival strategies in business. MSMEs are required to be able to adapt to existing business developments because a business that can survive is a business that is responsive to the times.

The development of a region in the era of globalization is very dependent on the economic sector as a measure of the success of the government. The role of society in national development, especially in economic development, is Micro, Small and Medium Enterprises. The position of MSMEs in the national economy has an important and strategic role. This condition is very possible because the existence of MSMEs is quite dominant in the Indonesian economy. MSMEs after the economic crisis continued to increase from year to year. This also proves that MSMEs are able to survive in the midst of an economic crisis. MSMEs are also proven to absorb a larger workforce in the national economy. With so many workers absorbed, the MSME sector was able to increase people's income.

Thus, MSMEs are considered to have a strategic frole in reducing unemployment and poverty. For the contribution and role of MSMEs, it is important for the government to continue to support UMKM through strengthening so that their role as pillars in building the nation's economy can run optimally.

Economic development is an urgent matter in a country, especially in increasing income and improving people's welfare. In macroeconomic analysis, economic growth is the rate of increase of per capita income which is described as a description of a country's economy and the level of social welfare. The role of society in national development, especially in economic development, is Micro, Small and Medium Enterprises. The position of Micro, Small and Medium Enterprises (MSMEs) in the national economy has an important and strategic role. This condition is very possible because the existence of MSMEs is quite dominant in the Indonesian economy, due to the large number of industries present in every economic sector, a large potential in employment, and the contribution of MSMEs in the formation of Gross Domestic Product (GDP) is very dominant. Another reason is that micro and small businesses have advantages in the fields of utilizing natural resources and are labor intensive, especially in the agricultural sector of plantation food crops, livestock, fisheries, trade and restaurants. Medium-sized enterprises have advantages in creating added value in the hotel, finance, leasing, MSME and forestry sectors.

Creative products have great potential to be able to deliver a city that has this industry to become a city with an advanced and independent creative economy. The use of information technology for the management of business resources for active products has been neglected, which in turn has administrative, financial, process, access to banking and financial institutions weaknesses. Good management governance often becomes an obstacle in terms of efficiency and effectiveness for inefficient creative products that will have a high-cost component. The main objective of economic development is to increase the number of goods and services as well as job opportunities for the community. The implementation of economic development must involve all levels of society and the government in taking regional development initiatives using all available support resources and designing and building regional economies [5].

Various efforts have been made by the government to advance the people's economy, one of which is by building various models of creative economy industries in various regions. Micro, Small and Medium Enterprises (MSMEs) are one of the driving forces for economic development, as well as the development of the number of MSMEs in North Sumatra which is quite good, namely around 2.8 million business units. This can make a pretty good contribution to economic growth in North Sumatra and regarding the development of competitive MSMEs, social and entrepreneurial training programs, entrepreneurial apprenticeships, business incubators and increased funding support by the Government through the Cooperative and Micro Small Business Revolving Fund Management Institution. and Medium and People's Business Credit in North Sumatra.

The achievements for the development of UMKM (MSMEs) entrepreneurs are 50,47\% in various activities and training for UMKM in North Sumatera. The characteristics inherent in MSMEs in North Sumatera could be strengths or strengths that actually become growth constraints. The combination of strengths and weaknesses as well as their interaction with external situations will determine the prospects for the development of MSMEs. The economic sector in North Sumatra is the sector that contributes the most to the creation of job opportunities and sources of income, especially in low-income rural areas. Micro, Small and Medium Enterprises, which are one component of the manufacturing sector, as a whole have a very large share in creating jobs for the community.

The contribution of micro, small and medium enterprises to the economy of North Sumatra can be viewed from two important aspects, namely aspects of aggregate production formation and employment. The contribution of micro, small and medium enterprises to aggregate production and labor absorption is higher than the contribution of large businesses. However, the productivity of micro and small businesses is much lower than the productivity of medium and large businesses. On the other hand, the labor income in micro and small businesses is lower than the labor income in medium and large businesses. The productivity of MSMEs, which is a benchmark for the successful development of MSMEs itself, is influenced by several factors, including the employment of MSMEs and the capital/investment structure of MSMEs, as well as the number of MSMEs 
units scattered throughout the region, especially North Sumatra. [6].

In the form of efforts to support the growth and sustainable Corporation of MSMEs in North Sumatra, various concrete efforts must be made, such as providing assistance and providing easy working capital loans for MSMEs to be able to develop products and increase the quality of their production output. One indicator of the progress of MSMEs is being able to finance short-term operations well, then MSMEs are also required to continue to provide product innovation and adjust it based on market demand and cross-culture conditions of the local community. The Indicator of the ability to survive in business competition for the MSME category is if it is able to increase the economic value added (EVA) of the business. The existence of economic value added (EVA) becomes relevant for measuring performance based on value because EVA is a measure of economic value added generated by MSMEs as a result of management activities or strategies. With the existence of EVA, MSME owners will only reward activities that add value and remove activities that damage or reduce the overall value of an MSME. Value added activities can be separated from non-value-added activities based on the value-added assessment process.

Economic Value Added helps management in setting internal goals (internal goal setting) of MSMEs so that goals are guided by long-term implications and not just short-term. In terms of investment, EVA provides guidelines for project acceptance decisions (capital budgeting decisions), and in terms of evaluating management's routine performance (performance assessments), EVA helps achieve value added activities. EVA also helps establish a correct payroll system or incentives (incentive compensation) where management is encouraged to act as owner. The process of applying economic value added in the MSME sector is how to create innovative products that have high creative value, so that at low costs they can generate greater profits. One of the ways to realize value added in the MSME sector can be by making a new breakthrough, namely by using the method of offering products and MSME businesses into joint ventures (open access) and turning the business unit into a medium-scale publicly listed company called the Indonesian Stock Exchange acceleration board method.

\section{Problems Identification}

Based on the background above, there are problems associated with this research. These problems are identified as follows:

1. There are obstacles in the process of developing the MSME sector in the province of North Sumatra amid the Covid-19 pandemic.

2. The MSME sector is increasingly difficult to carry out a sustainable process in adapting to the development of the global era

\section{Problems Formulation}

Based on the background above, there problem formulations in this study are:

1. How to overcome obstacles in the development process of the MSME sector in North Sumatera?

2. What is the Economic Value Added Business Development Model for the MSME sector in North Sumatera?

3. What is the process of implementing MSMESs into a public company using the Indonesia Stock Exchange Acceleration Board method?

\section{Purpose}

The scientific research carried out is aimed at providing recommendations for survival strategies (sustainable) for the MSME sector, especially in the province of North Sumatra in doing business amid the Covid-19 pandemic.

\section{Benefits}

The scientific research carried out is expected to provide benefits to the MSME business sector, especially in the province of North Sumatra, to add references and references as a model for managing MSMEs to create innovative creative products to support Indonesia's economic development.

\section{THEORETICAL BASIS}

\section{Definition of MSMES}

Micro, Small, and Medium Enterprises (MSMEs) have different definitions in each literature according to several agencies or institutions and even laws. In accordance with Law Number 20 of 2008 concerning Micro, Small and Medium Enterprises (MSMEs), MSMEs are defined as follows:

a. Micro business is a productive business owned by an individual and/or an individual business entity that meets the criteria of a Micro Business as regulated in this Law.

b. Small Business is a productive economic business that stands alone, which is carried out by an individual or a business entity that is not a subsidiary or branch of a company that is owned, controlled, or is a part, either directly or indirectly, of a Medium or Large Business criteria for Small Business as referred to in this Law.

c. Medium Business is a productive economic business that stands alone, which is carried out by an individual or a business entity that is not a subsidiary or branch of a company that is owned, controlled, or is a part, either directly or indirectly, with a Small or Large Business with total assets. net or annual sales proceeds as regulated in this Law. 


\section{Characteristic of MSMEs in Indonesia}

In the characteristics here, there are four reasons that explain the strategic position of MSMEs in Indonesia. First, MSMEs do not require large capital like large MSMEs so that the formation of this business is not as difficult as large businesses. Second, the required labor does not require a certain formal education. Third, most of them are located in rural areas and do not need infrastructure like large MSMEs. Fourth, MSMEs are proven to have strong resilience when Indonesia is hit by an economic crisis.

\section{Economic Value Added (EVA)}

EVA is a measure of the actual profit of an MSME in the current year, the value of EVA shows the actual remaining profit after the MSME net profit is reduced by all capital costs including the cost of equity. According to Brigham and Houston [1] EVA is an estimate of the actual economic profit of the business for the year concerned. EVA reflects the profit that remains after the cost of all capital, including equity capital, has been deducted.

Young and O'Byrne [12], the notion of EVA is based on the idea of economic profit, which states that wealth is only created when an MSME includes operational and capital costs. In this narrow sense, EVA is really only an alternative way of assessing the performance of MSMEs. The assessment of financial performance is measured by the following conditions:

1. If EVA $>0$, then the financial performance of MSMEs can be said to be good, so that a change in economic value occurs.

2. If $\mathrm{EVA}=0$, then the financial performance of MSMEs is economically even.

3. If EVA $<0$, then the financial performance of MSMEs is said to be not good because the profits obtained do not meet the expectations of the funders, so that there is no additional economic value for MSMEs.

Every UMKM certainly wants the value of EVA to increase continuously, because EVA is a fundamental measure of the rate of return on capital. There are several ways to increase the value of MSME EVA [10], namely:

1. Increase profit (profit) without increasing capital

2. Reducing the use of capital.

3. Investing in projects with high returns.

\section{Acceleration Board}

Acceleration Board is a Registration Board provided to list shares of Issuers with Small-Scale Assets or Issuers with Medium-Scale Assets as referred to in Financial Services Authority Regulation Number 53 / POJK.04 / 2017 concerning Registration Statements for Public Offerings and Capital Increase by Providing Rights PreOrder Securities by Issuers with Small-Scale
Assets or Issuers with Medium-Scale Assets and has not been able to meet the requirements on the Development Board. The Acceleration Board Listing Regulation was enforced by the IDX on July 22, 2019. After becoming public MSMEs, MSMEs can take advantage of the capital market to obtain further funding, including through a limited public offering, which offers are limited to investors who already own MSME shares, or through a secondary offering and private placement. MSMEs will also find it easier to attract strategic investors to invest in MSME stocks.

By becoming a public UMKM whose shares are traded on the Exchange, banks or other financial institutions will be able to get to know and have more trust in MSMEs. At any time, banks can find out about the financial condition of MSMEs through various disclosures announced by MSMEs through the Exchange. Under these conditions, not only will the lending process be relatively easier than lending to unfamiliar MSMEs, but the interest rate charged may also be lower given the credit risk for open MSMEs that is relatively smaller than credit risk for closed MSMEs.

\section{Initial Public Offering (IPO)}

Initial Public Offering (IPO) or commonly referred to as going public is a condition in which a company first releases its shares to be sold to the general public through the Stock Exchange. IPO offers various benefits for MSMEs in order to develop their business, so this method is often used by MSMEs, both small, medium and large scale. In the management of the Indonesian Stock Exchange, it was explained that in order to support the growth of MSMEs in Indonesia, the IDX Incubator program was held, which is one of the Indonesian Stock Exchange programs to provide knowledge to MSMEs about IPO, legal aspects for start- ups, and various other strategic information.

\section{RESEARCH METHOD}

This research includes the type of literature study, research by looking for theoretical references and scientific journals that are relevant to the cases or problems found. The theoretical references obtained by the literature study serve as the basis for study foundations and the main tool in conducting research. This research uses literature studies, analysis based on several previous studies and scientific journals that discuss Economic Value Added as an indicator of good performance assessment of an MSME. This study aims to see the potential of the acceleration board method and the Initial Public Offering (IPO) of the Indonesia Stock Exchange in making it easier for MSMEs to develop and be sustainable in the era of the Covid-19 pandemic. 


\section{DISCUSSION}

\section{Increasing the Economic Value Added (EVA) of the MSME Sector in the province of North Sumatra}

Separation of value added activities from non-value added activities begins with an activity analysis process. Activity analysis is "the process of identifying, describing, of evaluating the activities an organization performs" [2]. This activity analysis aims to identify and eliminate all unnecessary activities, and ultimately increase the efficiency of all necessary activities. Activity analysis can also mean adding value added activities to an MSMEs business. A performance measurement system in MSMEs must be able to distinguish value added activities from non-value added activities.

This division is necessary so that organizational management can focus on reducing costs arising from activities that do not add value. Reducing costs due to non-value-added activities is aimed at increasing the efficiency of the overall organization. "Reporting nonvalue added costs separately encourages managers to place more emphasis on controlling nonvalue added activities. Furthermore, tracking these costs over time permits managers to assess the effectiveness of their activity-management programs" [2].

MSME management can do many things to create added value, but in principle EVA will increase if management does one of the following three things [8]:

- Increase operating profit without additional capital.

- Investing new capital into projects that get a return greater than the cost of existing capital.

- Withdrawing capital from business activities that are not profitable.

Increasing operating profit without additional capital means that management can use MSME assets efficiently to obtain optimal profits. In addition, by investing in projects that receive a return greater than the cost of capital used means that management only takes quality projects and increases the value of MSMEs. Economic Value Added (EVA) also encourages management to focus on processes within MSMEs that add value and eliminate activities or processes that do not add value. The calculation of the EVA of an MSME is a complex and integrated process because MSMEs must first determine the cost of capital.

\section{Strategy for the Acceleration Board in the MSMEs Sector in North Sumatra}

Acceleration Board is a Registration Board provided to list shares of Issuers with Small-Scale Assets or Issuers with Medium-Scale Assets as referred to in Financial Services Authority Regulation Number 53 / POJK.04 / 2017 concerning Registration Statements for Public Offering and Capital Increase by Providing Rights PreOrder Securities by Issuers with Small-Scale Assets or
Issuers with Medium-Scale Assets and has not been able to meet the requirements on the Development Board. The Acceleration Board Listing Regulation was enforced by the IDX on 22 July 2019.

\section{Legal Basis}

a. Stipulation of OJK Regulations Regarding Public Offerings for Issuers with Small or Medium Scale Assets In 2017 OJK has enacted POJK Number 53 / POJK.04 / 2017 concerning Registration Statements for Public Offering and Capital Increase by Providing Pre-emptive Rights by Issuers with Small-Scale Assets or Issuers with Medium-Scale Assets.

b. Characteristics of Companies with Small and Medium Scale Assets Companies with Small and Medium Scale Assets have their own characteristics, so they need to be specifically regulated in terms of requirements, obligations and sanctions.

\section{Criteria}

The target of Prospective Companies Listed on the Acceleration Board are companies with small or medium-scale assets whose classification has been regulated in POJK Number 53 / POJK.04 / 2017.

\section{CONCLUSION}

Based on the results of research and discussion, the conclusions in this scientific research are as follows:

a. Various obstacles that are very diverse, especially in terms of funding and capitalization of MSMEs are factors that greatly affect growth and indicators of whether or not the MSME sector is sustainable. This has become a focus for reforming and creating MSME business innovations, especially in North Sumatra.

b. One of the strategies to increase added value for the MSME sector in North Sumatra is by using the Economic Value-Added method and implementing efforts to cooperate with the Indonesian Stock Exchange through the acceleration board mechanism and Initial Public Offering (IPO) to obtain long-term funding convenience and introduce MSME business units to the wider community to become a middleclass public company.

\section{REFERENCES}

[1] Brigham, Eugene FandJoel F. Houston. Fundamentals of Financial Management.12th Edition. Mason: South-Westtern Cengage Learning. 2009.

[2] Don, R. Hansen, and Marryanne M. Mowen. Management Accounting. Second Edition. Cincinnati, Ohio: South-Western Publishing Co, 1992.

[3] Irene Neysa Adiguna, Sri Murni, Johan Tumiwa. Analisis Kinerja Keuangan Dengan Menggunakan 
Metode Economic Value Added (EVA) Pada Perusahaan Plastik dan Kemasan Yang Terdaftar Di Bursa Efek Indonesia Periode Tahun 2013-2015. Jurnal EMBA. Vol. 5 No.2 Juni 2017 pp. 423-442.

[4] Lisa Linawati. EVA Sebagai Ukuran Keberhasilan Kinerja Manajemen Perusahaan. Juranak Akuntansi dan Keuangan, Vol.7, No. 1. 1999.

[5] Pujiono, Akselarasi Peningkatan Usaha Mikro, Kecil, dan Menengah melalui Pendidikan, Proceding Seminar Nasional Peningkatan Kapabilitas UMKM dalam Mewujudkan UMKM Naik Kelas. 2012.

[6] Muchdarsyah Sinungan. Produktivitas. Jakarta: Bumi Aksara. 2005.

[7] Rudianto. Akuntansi Manajemen. Jakarta: PT Gramedia. 2006.

[8] Stewart, Stern. EVA (Economic Value Added): The Real Key to Creating Wealth. Wiley \& Sons, Inc., Canada. 1998.

[9] Sudati Nur Sarfiah. Economic ValueAdded: Pengukuran Penciptaan Nilai Perusahaan. Majalah Usahawan No. 04 Th XXVI April 1997. 1997. pp 10-13.

[10] Widayanto, G., EVA/NITAMI: Suatu terobosan baru dalam pengukuran kinerja perusahaan.Manajemen Usahawan Indonesia, 12, 1993. pp 49-53.

[11] W Laura Hardilawati - Jurnal Akuntansi dan Ekonomika, 2020.

[12] Young, David S. \& O Byrne, Stephen F. EVA \& MANAJEMEN BERDASARKAN

NILAI: Panduan Praktis Untuk Implementasi, Edisi 1, Jakarta:Salemba Empat. 2001. 